\title{
ANALISIS KESULITAN DALAM PERENCANAAN PEMBELAJARAN TEMATIK DI SEKOLAH DASAR
}

\author{
Dhiniaty Gularso \\ Program Studi PGSD FKIP UPY \\ Email: dhiniatygularso@yahoo.com
}

\begin{abstract}
Pembelajaran tematik adalah pembelajaran yang dilaksanakan di sekolah dasar (SD) khususnya kelas rendah yaitu kelas 1, 2 dan 3. Selama ini, pembelajaran tematik masih dirasakan sulit oleh sebagian besar guru dan calon guru SD. Kesulitan-kesulitan tersebut diantaranya kesuliitan dalam perencanaan pembelajaran tematik, Kesulitan-kesulitan ini berdampak pada kesiapan dan kemampuan guru dalam melaksanakan pembelajaran dikelas.

Tujuan penelitian ini adalah menganalisis kesulitan yang dialami mahasiswa program studi PGSD dalam hal merencanakan pembelajaran tematik untuk kelas I, II dan III di sekolah dasar. Penelitian ini adalah penelitian kuantitatif deskriptif. Populasi penelitian adalah mahasiswa Program Studi PGSD FKIP UPY yang menempuh mata kuliah Pembelajaran Tematik sebanyak 266 mahasiswa. Metode pengambilan sampel adalah purposive sampling yaitu peserta ujian PPL I yang mendapatkan Pembelajaran Tematik sebanyak 24 mahasiswa. Data yang dikumpulkan berupa angket. Analisis data menggunakan modus.

Hasil penelitian menjunjukkan bahwa urutan langkah yang paling sulit hingga yang paling mudah dalam perencanan pembelajaran tematik calon guru SD adalah sebagai berikut (1) memetakan SK/KD dan indikator kedalam tema (2) menentukan indikator (3) menentukan tema dan minggu efektif (4) menyusun jaring-jaring tem satu semester (5) menyusun jaring tema per minggu (6) menyusun silabus (7) menyusun jaring tema pertema (8) menyususn penilaian (9) menyusun RPP (10) menyusun jaring-jaring tema perhari dan (11) menyusun bahan ajar.

Kata kunci : Analisis kesulitan, perencanaan pembelajaran tematik, sekolah dasar
\end{abstract}

\section{ANALYSIS OF DIFFICULTY IN PLANNING OF TEMATIC LEARNING IN ELEMENTARY SCHOOL}

Thematic learning is a lesson that is carried out in elementary schools (SD), especially low grade of classes 1, 2 and 3. During this time, thematic learning is still felt difficult by most teachers and prospective elementary school teachers. These difficulties include the difficulty in thematic learning planning, These difficulties affect the readiness and ability of teachers in implementing classroom learning.

The purpose of this study is to analyze the difficulties experienced by PGSD students in planning thematic lessons for classes I, II and III in primary schools. This research is descriptive quantitative research. The population of this research is the students of PGSD FKIP UPY which take the subjects of Thematic Learning as many as 266 students. The sampling method is purposive sampling that is the participants of PPL I exam which get Thematic Learning as many as 24 students. The data collected were questionnaires. data is analyzed by using mode.

The results of the study show that the most difficult sequence of steps to the easiest in the planning of thematic teaching of prospective elementary teachers is as follows: (1) map the SK / $\mathrm{KD}$ and indicators into the theme (2) determine the indicators (3) determine the theme and the effective week (4) compiling one semester tem web (5) composing the theme nets per week (6) arranging the syllabus (7) construct the theme web (8) formulate the assessment (9) formulate the RPP (10) compose the theme webs per day and (11) construct the nets of the theme per week (6) compile teaching materials.

Keywords: Analysis of difficulties, thematic learning planning, primary school 



\section{A. Latar Belakang Penelitian}

Peraturan Menteri Pendidikan Nasional Nomor 22 tahun 2006 menyebutkan bahwa pembelajaran untuk kelas I, II, dan III dilaksanakan melalui pendekatan tematik. Berdasarkan amanah pemerintah yang telah disebutkan diatas maka pendidikan di sekolah dasar kelas rendah yaitu kelas 1,2 dan 3 wajib dilaksanakan dengan pembelajaran berbasis tema atau yang dikenal dengan pembelajaran tematik.

Pembelajaran tematik adalah pembelajaran yang dilaksanakan di sekolah dasar (SD) khususnya kelas rendah yaitu kelas 1, 2 dan 3. Peserta didik di SD sesuai dengan tingkat perkembangan kognitif mereka dibedakan dalam lower dan upper class atau kelas rendah/awal dan kelas atas. Peserta didik di kelas awal umumnya duduk di tahun pertama hingga tiga (Prasetyo, 2008).

Semenjak diverlakukan Permendiknas 22 Tahun 2006, pembelajaran tematik masih dirasakan sulit oleh sebagian besar guru dan calon guru SD. Kesulitan-kesulitan tersebut diantaranya kesuliitan dalam perencanaan pembelajaran tematik, Kesulitan-kesulitan ini berdampak pada kesiapan dan kemampuan guru dalam melaksanakan pembelajaran dikelas. Keluhan-keluhan yang tak terselesaikan dan tanpa adanya pemecahan ini akan menimbulkan permasalahan dan jika tidak diselesaikan akan menimbulkan kebingungan bagi guru dan berimbas pada tidak terlaksananya pembelajaran

Berdasarkan kesenjangan antara kondisi yang diharapkan oleh pemerintah dengan kondisi di lapangan yaitu guru asih kesulitan dalam pembelajaran teatik maka peneliti memandang perlu untuk dilkaukan penelitian yang bertujuan untuk menganalisis kesulitan yang dialami mahasiswa program studi PGSD dalam hal merencanakan pembelajaran tematik untuk kelas I, II dan III di sekolah dasar.

\section{B. Rumusan Masalah Penelitian}

Berdasarkan latar belakang tersebut maka rumusan masalah dalam penelitian ini adalah bagaimana kesulitan yang dialami mahasiswa program studi PGSD dalam hal merencanakan pembelajaran tematik untuk kelas I, II dan III di sekolah dasar?

\section{Tujuan Penelitian}

Tujuan penelitian ini adalah menganalisis kesulitan yang dialami mahasiswa program studi PGSD dalam hal merencanakan pembelajaran tematik untuk kelas I, II dan III di sekolah dasar.

\section{Manfaat Penelitian}

Manfaat yang diperoleh dari penelitian ini adalah setelah mengetahui kesulitan dalam perencanaan pembelajaran tematik, dosen dapat melakukan perbaikan 
pembelajaran tematik dalam hal metode dan strategi.

\section{E. Kajian Pustakan}

Dalam pelaksanaan pembelajaran tematik, perlu dilakukan beberapa hal yang meliputi tahap perencanaan yang mencakup kegiatan pemetaan kompetensi dasar, pengembangan jaringan tema, pengembangan silabus dan penyusunan rencana pelaksanaan pembelajaran.

a. Pemetaan Kompetensi Dasar

Kegiatan pemetaan ini dilakukan untuk memperoleh gambaran secara menyeluruh dan utuh semua standar kompetensi, kompetensi dasar dan indikator dari berbagai mata pelajaran yang dipadukan dalam tema yang dipilih.

Kegiatan yang dilakukan adalah:

1) Penjabaran Standar Kompetensi dan Kompetensi Dasar ke dalam Indikator Melakukan kegiatan penjabaran standar kompetensi dan kompetensi dasar dari setiap mata pelajaran ke dalam indikator. Dalam mengembangkan indikator perlu memperhatikan hal-hal sebagai berikut:

a. Indikator dikembangkan sesuai dengan karakteristik peserta didik

b. Indikator dikembangkan sesuai dengan karakteristik mata pelajaran c. Dirumuskan dalam kata kerja oprasional yang terukur dan/atau dapat diamati

2) Menentukan tema

a) cara penentuan tema

Dalam menentukan tema dapat dilakukan dengan dua cara yakni:

Cara pertama, mempelajari standar kompetensi dan kompetensi dasar yang terdapat dalam masing-masing mata pelajaran, dilanjutkan dengan menentukan tema yang sesuai.

Cara kedua, menetapkan terlebih dahulu tema-tema pengikat keterpaduan, untuk menentukan tema tersebut, guru dapat bekerjasama dengan peserta didik sehingga sesuai dengan minat dan kebutuhan anak.

b) Prinsip Penentuan tema

Dalam menetapkan tema perlu memperhatikan beberapa prinsip yaitu:

- Memperhatikan lingkungan yang terdekat dengan siswa:

- Dari yang termudah menuju yang sulit

- Dari yang sederhana menuju yang kompleks

- Dari yang konkret menuju ke yang abstrak.

- Tema yang dipilih harus memungkinkan terjadinya proses berpikir pada diri siswa

- Ruang lingkup tema disesuaikan dengan usia dan perkembangan siswa, termasuk minat, kebutuhan, dan kemampuannya 
b. Identifikasi dan analisis Standar Kompetensi, Kompetensi dasar dan Indikator

Lakukan identifikasi dan analisis untuk setiap Standar Kompetensi, Kompetensi Dasar dan indikator yang cocok untuk setiap tema sehingga semua standar kompetensi, kompetensi dasar dan indikator terbagi habis.

b. Menetapkan Jaringan Tema

Buatlah jaringan tema yaitu menghubungkan kompetensi dasar dan indikator dengan tema pemersatu. Dengan jaringan tema tersebut akan terlihat kaitan antara tema, kompetensi dasar dan indikator dari setiap mata pelajaran. Jaringan tema ini dapat dikembangkan sesuai dengan alokasi waktu setiap tema.

c. Penyusunan Silabus

Hasil seluruh proses yang telah dilakukan pada tahap-tahap sebelumnya dijadikan dasar dalam penyusunan silabus. Komponen silabus terdiri dari standar kompetensi, kompetensi dasar, indikator, pengalaman belajar, alat/sumber, dan penilaian.

d. Penyusunan Rencana Pembelajaran

Untuk keperluan pelaksanaan pembelajaran guru perlu menyusun rencana pelaksanaan pembelajaran.
Rencana pembelajaran ini merupakan realisasi dari pengalaman belajar siswa yang telah ditetapkan dalam silabus pembelajaran. Komponen rencana pembelajaran tematik meliputi:

1) Identitas mata pelajaran (nama mata pelajaran yang akan dipadukan, kelas, semester, dan waktu/banyaknya jam pertemuan yang dialokasikan).

2) Kompetensi dasar dan indikator yang akan dilaksanakan.

3) Materi pokok beserta uraiannya yang perlu dipelajari siswa dalam rangka mencapai kompetensi dasar dan indikator.

4) Strategi pembelajaran (kegiatan pembelajaran secara konkret yang harus dilakukan siswa dalam berinteraksi dengan materi pembelajaran dan sumber belajar untuk menguasai kompetensi dasar dan indikator, kegiatan ini tertuang dalam kegiatan pembukaan, inti dan penutup).

5) Alat dan media yang digunakan untuk memperlancar pencapaian kompetensi dasar, serta sumber bahan yang digunakan dalam kegiatan pembelajaran tematik sesuai dengan kompetensi dasar yang harus dikuasai. 
6) Penilaian dan tindak lanjut (prosedur dan instrumen yang akan digunakan untuk menilai pencapaian belajar peserta didik serta tindak lanjut hasil penilaian).

\section{F. METODE PENELITIAN}

\section{Jenis Penelitian}

Penelitian ini adalah penelitian kuantitatif deskriptif. Artinya pada penelitian ini data yang telah diperoleh akan ditabulasikan menggunakan statistic sederhana yaitu modus atau angka yang paling banyak muncul pada setiap langkah perencanaan pembelajaran tematik.

\section{Populasi dan Sampel Penelitian}

Populasi penelitian ini adalah calon guru SD atau mahasiswa PGSD FKIP UPY angkatan 2014 berjumlah 266 mahasiswa. Metode penentuan sampel adalah purposive sampling yaitu peserta ujian PPL I yang memperoleh undian pembelajaran tematik. Hal ini dilakukan dengan pertimbangan peserta ujian PPL 1 lebih serius mengerjakan SSP sehingga untuk mencari data untuk mengetahui kesulitan dalam perencanaan atau penyusunan SSP lebih dapat dilakukan. Sampel berjumlah 24 mahasiswa yang terdiri atas kelas A1,A2,A3,A4,A5 dan A6 angkatan 2014.

\section{Metode Pengumpulan Data}

Data yang dibuthkan untuk mengngkap kesulitan dalam perencanaan pembelajaran tematik adalah data primer berupa nagket terbuka. Adapun kisi-kisi analisis kesulitan mahasiswa adalah mengacu pada langkah-langkah penyusunan perencanaan pembelajaran tematik sebagai berikut.

1. Menentukan indikator

2. Menentukan tema dan minggu efektif

3. Memetakan SK/KD dan indikator kedalam tema

4. Menyusun jaring-jaring tema satu semester

5. Menyusun jaring-jaring tema per tema

6. Menyusun jaring tema per tema

7. Menyusun jaring tema per minggu

8. Menyusun jaruing tema per hari

9. Menyusun Silabus

10. Menyusun Rencana Pelaksanaan Pembelajaran

11. Menyusun Bahan Ajar

12. Menyusun Penilaian

\section{Metode Analisis Data}

Data yang telah diperoleh dianalisis menggunakan modus yaitu angka yang paling banyak muncul pada setiap langkah perencanaan pembelajaran tematik. Urutan yang paling banyak muncuk tersebut yang kemudian menjadi urutan dalam kesulitan pembelajaran tematik.

\section{G. Hasil Dan Pembahasan Penelitian}


Penelitian ini merupakan penelitian kuantitatif desktiptif dimana data berasal dari angket yang ditujukan kepada calon guru SD yang mengikuti ujian Praktik Pengalaman Lapangan (PPL) 1 atau microteaching di Program Studi PGSD FKIP UPY. Pemilihan sampel bertujuan yaitu peserta ujian PPL 1 dikarenakan sampel tersebut lebih serius atau lebih merasakan kesulitan dalam menyusun Subject Spesifik Paedagogik (SSP) dibandingkan dengan mahasiswa praktikan PPL lain.

Angket yang disusun berasal dari pedoman atau langkah-langkah penyusunan perencanaan pembelajaran tematik dari Badan Nasional Standar Pendidikan (BSNP) tahun 2006. Angket yang telah disusun telah divalidari oleh ahli pembelajaran tematik dari Program Studi PGSD FKIP UPY yaitu Hermawan Wahyu Setiadi, M.Pd. Hasil validasi angket menyatakan bahwa angket dapat digunakan untuk mengambil data penelitian ini dan berada pada kategori baik.

Hasil rekpitulasi angket penelitian menunjukkan bahwa langkah memetakan $\mathrm{SK} / \mathrm{KD}$ dan indikator kedalam tema merupakan langkah paling sulit yang dikerjakan oleh calon guru SD sedangkan langkah yang paling mudah adalah menyusun bahan ajar pembelajaran tematik. Berdasarkan Tabel 3 dapat diketahui hasil urutan langkah yang paling sulit hingga yang paling mudah (1) memetakan SK/KD dan indikator kedalam tema (2) menentukan indikator (3) menentukan tema dan minggu efektif (4) menyusun jaring-jaring tem satu semester (5) menyusun jaring tema per minggu (6) menyusun silabus (7) menyusun jarring tema pertema (8) menyususn penilaian (9) menyusun RPP (10) menyusun jarring-jaring tema perhari dan (11) menyusun bahan ajar.

Tabel 3. Hasil Penelitian

\begin{tabular}{|c|c|c|c|c|c|c|c|c|c|c|c|c|c|c|}
\hline Langkah & \multicolumn{11}{|c|}{ Urutan Mudah ke Sulit } & $\mathrm{Jml}$ & $\%$ & HA \\
\hline Perencanaan & 1 & 2 & 3 & 4 & 5 & 6 & 7 & 8 & 9 & 10 & 11 & & & \\
\hline $\begin{array}{l}\text { Menentukan } \\
\text { indicator }\end{array}$ & 5 & 5 & 6 & 0 & 2 & 2 & 3 & 1 & 0 & 0 & 0 & 24 & $25 \%$ & 2 \\
\hline $\begin{array}{l}\text { Menentukan tema } \\
\text { dan minggu efektif }\end{array}$ & 1 & 3 & 0 & 4 & 3 & 3 & 4 & 1 & 1 & 1 & 3 & 24 & $17 \%$ & 3 \\
\hline $\begin{array}{l}\text { Memetakan SK/KD } \\
\text { dan indikator } \\
\text { kedalam tema }\end{array}$ & 8 & 2 & 4 & 1 & 2 & 2 & 4 & 1 & 0 & 0 & 0 & 24 & $33 \%$ & 1 \\
\hline $\begin{array}{l}\text { Menyusun jaring- } \\
\text { jaring tema satu } \\
\text { semester }\end{array}$ & 2 & 3 & 1 & 2 & 2 & 5 & 2 & 4 & 1 & 2 & 0 & 24 & $21 \%$ & 4 \\
\hline $\begin{array}{l}\text { Menyusun jaring- } \\
\text { jaring tema per } \\
\text { tema }\end{array}$ & 0 & 3 & 4 & 1 & 2 & 0 & 2 & 4 & 6 & 1 & 1 & 24 & $25 \%$ & 7 \\
\hline
\end{tabular}




\begin{tabular}{|c|c|c|c|c|c|c|c|c|c|c|c|c|c|c|}
\hline Langkah & \multicolumn{11}{|c|}{ Urutan Mudah ke Sulit } & \multirow[t]{2}{*}{ Jml } & \multirow[t]{2}{*}{$\%$} & \multirow[t]{2}{*}{ HA } \\
\hline Perencanaan & 1 & 2 & 3 & 4 & 5 & 6 & 7 & 8 & 9 & 10 & 11 & & & \\
\hline $\begin{array}{l}\text { Menyusun jaring } \\
\text { tema per minggu }\end{array}$ & 0 & 2 & 2 & 3 & 1 & 2 & 4 & 3 & 3 & 4 & 0 & 24 & $17 \%$ & 5 \\
\hline $\begin{array}{l}\text { Menyusun jaring } \\
\text { tema per hari }\end{array}$ & 2 & 0 & 2 & 3 & 3 & 1 & 0 & 4 & 0 & 3 & 6 & 24 & $25 \%$ & 10 \\
\hline Menyusun Silabus & 1 & 2 & 2 & 2 & 1 & 2 & 1 & 2 & 5 & 4 & 2 & 24 & $21 \%$ & 6 \\
\hline $\begin{array}{l}\text { Menyusun Rencana } \\
\text { Pelaksanaan } \\
\text { Pembelajaran }\end{array}$ & 2 & 1 & 1 & 1 & 4 & 1 & 1 & 1 & 1 & 8 & 3 & 24 & $33 \%$ & 9 \\
\hline $\begin{array}{l}\text { Menyusun Bahan } \\
\text { Ajar }\end{array}$ & 2 & 1 & 0 & 4 & 0 & 3 & 0 & 4 & 1 & 0 & 9 & 24 & $38 \%$ & 11 \\
\hline $\begin{array}{l}\text { Menyusun } \\
\text { Penilaian }\end{array}$ & 1 & 2 & 2 & 3 & 3 & 2 & 2 & 1 & 6 & 2 & 0 & 24 & $25 \%$ & 8 \\
\hline
\end{tabular}

Gambar 1 menunjukkan bahwa $34 \%$ calon guru SD mengalami langkah paling suit dalam merencanakan pembelajaran tematik adalah memetakan SK/KD dan indicator kedalam tema, sedangkan $21 \%$ sangat mengalami kesulitan pada menentukan indicator. Pada langkah perencanaan menyusun jarring tema satu semester, menyusun jarring tema perhari, menyusun RPP dan menyusun bahan ajar masing-masing dianggap sangat sulit oleh $8 \%$ calon guru SD. Sementara pada langkah menentukan tema dan minggu efektif, menyusun silabus dan menyusun penilaian dianggap sangat sulit bagi masingmasing langkah sebesar 4\% dari jumlah responden.

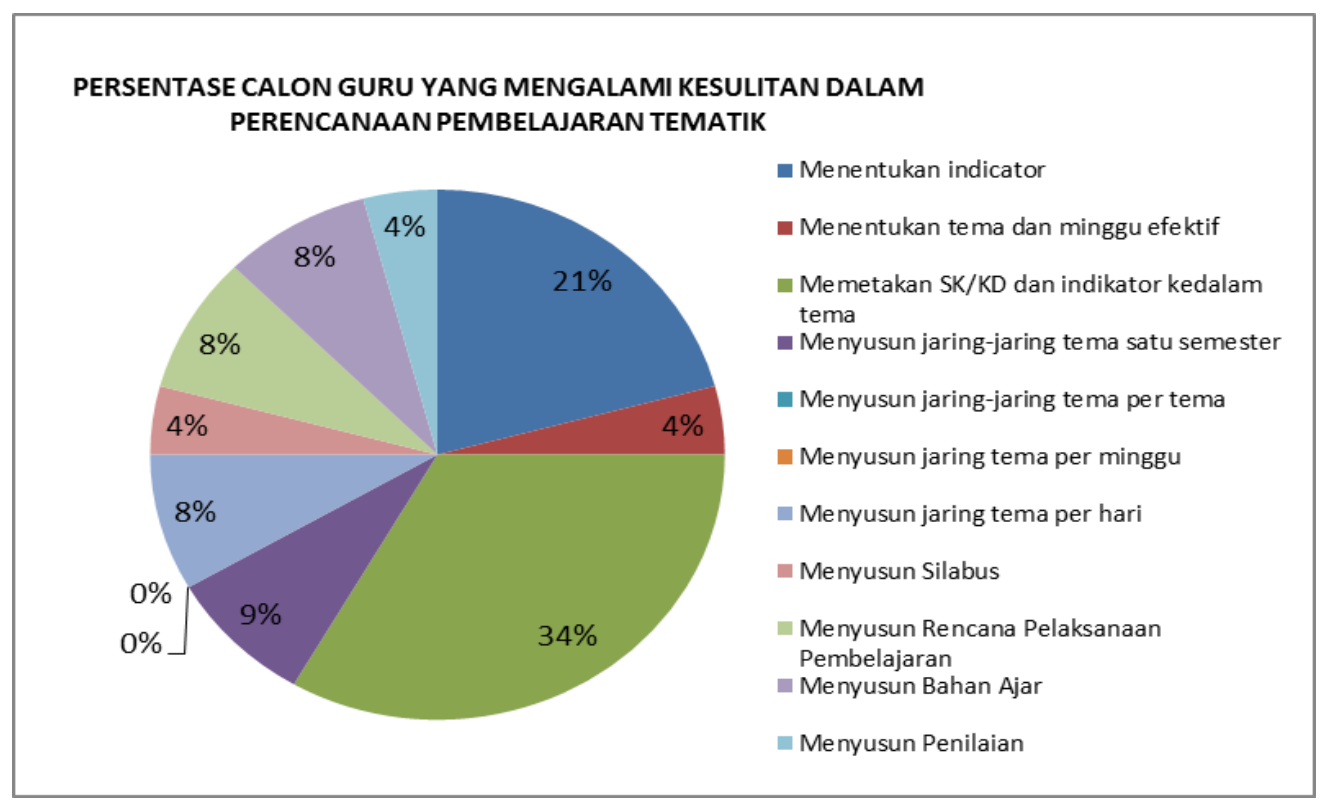

Gambar 1. Persentase Calon Guru Yang Mengalami Kesulitan Dalam Perencanaan Pembelajaran Tematik 
Berdasarkan Tabel 3. dapat diketahui pula bahwa selain $33 \%$ calon guru menganggap langkah paling sulit dalam perencanaan pembelajaran tematik adalah memetakan Standar Kompetensi/Kompetensi Dasar $(\mathrm{SK} / \mathrm{KD})$ dan indikator kedalam tema. Keterangan yang diperoleh dari angket menyebutkan bahwa penyebab dari hal ini dikarenakan calon guru harus menyesuaikan indikator yang dapat dihubungkan dengan indikator mata pelajaran lain. Pada langkah ini diperlukan daya imajinasi atau daya khayal tinggi dari calon guru SD dalam membayangkan pembelajaran yang akan dilakukan.

Kegiatan pemetaan ini dilakukan untuk memperoleh gambaran secara menyeluruh dan utuh semua standar kompetensi, kompetensi dasar dan indikator dari berbagai mata pelajaran yang dipadukan dalam tema yang dipilih. Kegiatan yang dilakukan antara lain (1) Identifikasi dan analisis Standar Kompetensi yaitu melakukan identifikasi dan analisis untuk setiap standar kompetensi yang cocok untuk setiap tema sehingga semua standar kompetensi terbagi habis (2) Identifikasi dan analisis Kompetensi Dasar yaitu melakukan identifikasi dan analisis untuk setiap kompetensi dasar yang cocok untuk setiap tema sehingga semua kompetensi dasar terbagi habis dan (3) Identifikasi dan analisis Indikator yaitu meakukan identifikasi dan analisis untuk setiap indikator yang cocok untuk setiap tema sehingga semua indikator terbagi habis (BSNP, 2006).

Beberapa calon guru merasa sulit menyesuaikan antara SK satu dengan SK lainnya sedangkan beberapa calon guru lainnya mengalami kesulitan pada menyesuaikan antara tema dengan SK/KD. Pada saat memetakan SK/KD dan tema kedalam indicator, calon guru harus memprediksi alur pembelajaran yang akan dilaksanakan. Selain itu bagaimana cara menghubungkan antara mata pelajaran juga harius sudah disiapkan atau diprediksikan sebelumnya agar pembelajaran tematik dapat terlaksana secara maksomal dan bukan menjadi pembelajarn berbasis bidang studi.

Sebanyak $21 \%$ calon guru menganggap hal tersulit kedua adalah menentukan indikator itu sendiri. Hal ini dikarenakan calon guru masih bingung menggunakan acuan Kata Kerja Operasional (KKO) dan kesulitannya pada mengurutkan dari yang termudah ke yang tersulit apalagi 
saat dituntut menyyusun indikator untuk proses, produk dan karakter. Selain itu calon guru masih bingung mengurutkan KKO berdasarkan karakteristik siswanya. Pada BSNP (2006), ada dua hal dalam menyusun indikator yaitu (1) indikator harus sisesuaikan dengan kebutuhan dan karaktersitik peserta didik dan karaktersitik mata pelajaran dan (2) indikator dirumuskan dalam kata kerja operasional yang dapat diukur dan diamati oleh siswa ataupun guru.

Langkah

pengembangan indikator adalah menganalisis tingkat kompetensi dalam SK dan KD. Hal ini diperlukan untuk memenuhi tuntutan minimal kompetensi yang dijadikan standar secara nasional. Sekolah dapat mengembangkan indikator melebihi standar minimal tersebut (BSNP, 2006). Berdasarkan angket yang diisi calon guru SD, kesulitan mereka dalam menyusun indikator adalah pada nomor dua yaitu merumuskan KKO yang sesuai dengan krakteristik siswa dan karakteristik mata pelajaran.

Tingkat kompetensi dapat dilihat melalui kata kerja operasional yang digunakan dalam SK dan KD. Tingkat kompetensi dapat diklasifikasi dalam tiga bagian, yaitu tingkat pengetahuan, tingkat proses, dan tingkat penerapan. Kata kerja pada tingkat pengetahuan lebih rendah dari pada tingkat proses maupun penerapan. Tingkat penerapan merupakan tuntutan kompetensi paling tinggi yang diinginkan (BSNP, 2006). Berdasarkan angket, calon guru mengalami kesulitan dalam menyusun indikatir ranah afektif, Kesulitan mereka terletak pada mengurutkan ranah afektif dari yang paling sederhana ke yang kompleks atau dari yang mudah ke sulit.

Hal tersulit ketiga pada perencanaan pembelajaran tematik adalah menentukan tema dan minggu efektif. Sebanyak $17 \%$ calon guru mengalami kesulitan menentukan tema dikarenakan harus merancang tema yang dapat mengikat keterpaduan antara SK/KD dan indikator yang telah dibuat. Sebagian calon guru mengalami kesulitan pada tuntutan variasi tema agar menarik bagi siswa. Kesulitan dalam menentukan tema yang dialami oleh calon guru SD adalah tema yang paling dekat dengan siswa bagi kelas III mengingat kelas III sudah merupakan peralihan ke kelas IV yang artinya peralihan pada tahap operasional kongkret ke abstrak. Selain itu, penentuan tema dari mudah ke sulit 
atau sederhana ke kompleks bagi siswa kelas III juga menjadi kendala sendiri bagi calon guru tersebut.

Kesulitan dalam menyusun minggu efektif terletak pada perhitungan mingu efektif per tema. Hal ini dikarenakan calon guru SD harus memprediksi kompleksitas, daya dukung dan intak siswa agar pembelajaran dalam satu tema tuntas sesuai dengan alokasi waktu yang ditentukan. Jadi, meskipun Permendiknas Nomor 22 Tahun 2006 telah memberikan acuan minggu efektif dalam satu tahun adalah 34-38 minggu efektif, namun untuk merinci kedalam satu semester atau tema, calon guru masih mengalami kesulitan.

Langkah keempat yang dianggap sulit adalah menyusun jaringjaring tema dalam satu semester. Sebanyak $21 \%$ calon guru mengatakan bahwa kesulitannya adalah memadukan $\mathrm{SK} / \mathrm{KD}$ dan indikator semua mata pelajaran dalam satu semester tidak mudah karena terkadang dirasa kurang pas dimasukkan dalam tema. Bahkan beberapa calon guru merasa didalam memadukan indikator pada SD/KD terkesan dipaksakan karena belum memiliki gambaran pembelajaran yang akan dilakukan. Kesulitan lain yang dialami adalah masalah teknis penulisan yaitu bagaimana memuat puluhan indicator per mata pelajaran yang ditematikkan dalam satu semester. Untuk mengerjakan hal tersebut diperlukan teknik penulisan tersendiri.

Sebanyak $17 \%$ calon guru menganggap bahwa menyusun jaringjaring tema per minggu merupakan hal tersulit kelima dalam langkah menyusun SSP. Hal ini dikarenakan mereka atau calon guru tersebut kesulitan menentukan tema yang cocok dalam satu minggu. Menurut mereka, cukup sulit membagi jaring tema per semester kedalam jaring tema per minggu karena harus menentukan minggu efektif terlebih dahulu. Pada saat menghitung minggu efektif selama satu semester harus menyesuaikan dengan Permendiknas 22 Tahun 2006 tentang Standar Isi yaitu minggu efektif untuk SD adalah 34-38 minggu efektif. Kalender pendidikan harus menjadi acuan dalam menentukan minggu efektif.

Menyusun silabus merupakan kesulitan keenam menurut calon guru SD dalam erencanaan pembelajaran tematik. Sebanyak 21\% calon guru menyatakan demikian. Hal ini dikarenakan banyak aspek yang perlu diperhatikan antara lain kegiatan 
belajar. Kegiatan belajar merupakan hal tersulit dalam merancang silabus karena menyesuaikan dengan indikator yang telah dibuat. Pernyataan calon guru SD pada penelitian ini sejalan dengan hasil penelitian Gularso (2010) yang menyatakan bahwa kesulitan yang dialami guru SD di Kecamatan Kasihan dalam pembelajaran tematik adalah penyusunan kegiatan belajar pada silabus.

Kesulitan ketujuh dalam perencanaaan pembelajaran tematik calon guru SD adalah menentukan jarring tema pertema. Sebanyak 25\% calon guru mengalamu kesulitan dikarenakan kesulitan terlebih dahulu pada menentukan tema besar untuk memadukan tema-tema kecil dari jaring tema satu semester. Seperti pada teori penentuan tema dari BSNP (2006) bahwa tema yang dibuat harus dari yang termudah ke yang paling sulit, dari yang kongkret ke abstrak, dari yang paling dekat dengan siswa SD, dari yang sederhana ke yang kompleks dan tema harus sesuai dengan kebutuhan dan karakteristik siswa SD yang bersangkutan.

Langkah perencanaan yang dianggap sulit selanjutnya yaitu menusun penilaian. Tabel 3 menunjukkan bahwa $25 \%$ calon guru memberikan urutan kedelapan untuk langkah ini. Mereka mengemukakan alasan untuk kesulitan dalam penilaian tergantung dari indikator yang ditentukan sebelumnya pada langkah pertama. Penilaian dalam pembelajaran tematik memang dilakukan per mata pelajaran karena yang dinilai adalah kompetensi dari masing-masing indikator per mata pelajaran. Jadi tematik itu merupakan pendekatan dalam pembelajaran saja, tetapi penilaian tetap per mata pelajaran sesuai dengan kompetensi yang telah dirumuskan pada saaat menyusun indicator pembelajaran. Beberapa calon guru SD mengalami kesulitan pada penyusunan rubric untuk penilaian yang bersifat afektif atau psikomotor.

Urutan kesulitan kesembilan untuk analisis kesulitan langkah perencanaan pembelajaran tematik adalah menyusun Rencana Pelaksanaan Pembelajaran (RPP). Sebanyak 33\% calon guru menyatakan demikian. Alasan mereka menyatakan bahwa penyusunan RPP tidak terlalu sulit bagi mereka adalah RPP tinggal menurunkan dan mengembangkan dari silabus. Pengembangan RPP terletak pada kegiatan belajar yang lebih didetailkan lagi daripada silabus. Keulitan yang dialami calon guru 
adalan membagi kegiatan yang dilakukan guru dan kegiatan yang dilakukan sisiwa. Selain itu, eksplorasi, elaborasi dan konfirmasi juga menjadi focus pengerjaan RPP.

Kesulitan terakhir atau yang dianggap paling mudah dalam langkah perencanaan pembelajaran tematik adalah penyusunan bahan ajar. Sebanyak 38\% calon guru memilih bahan ajar sebagai langkah yang paling mudah (Tabel 3). Hal ini dikarenakan bahan ajar sudah tersedia baik dari Buku Sekolah Elektronik (BSE) maupun buku-buku tematik yang banyak beredar di masyarakat. Beberapa calon guru SD mengembangkan bahan ajar yang ada dengan pengetahuan tambahan lain yang terdapat di internet agar bahan ajar lebih kontekstual.

\section{H. Simpulan Dan Saran}

\section{Simpulan}

Urutan langkah yang paling sulit hingga yang paling mudah dalam perencanaan pembelajaran tematik calon guru SD adalah sebagai berikut (1) memetakan $\mathrm{SK} / \mathrm{KD}$ dan indikator kedalam tema (2) menentukan indikator (3) menentukan tema dan minggu efektif (4) menyusun jaringjaring tem satu semester (5) menyusun jaring tema per minggu (6) menyusun silabus (7) menyusun jaring tema pertema (8) menyususn penilaian (9) menyusun RPP (10) menyusun jaringjaring tema perhari dan (11) menyusun bahan ajar.

\section{Saran}

Saran untuk LPTK adalah meningkatkan pembinaan dan pembimbingan pada kesulitan urutan 1 hingga 3 dimana calon guru masih banyak yang bingung dan ketiga hal tersebut yang merupakan inti permasalahan, Langkah ini bersifat domino sehingga jika langkah pertama sudah salah maka langkah selanjutnya juga sudah pasti salah. Saran untuk peneliti selanjutnya adalah sampel yang diambil lebih banyak lagi sehingga hasil lebih mendekati kebenaran.

\section{Daftar Pustaka}

Badan Standar Nasional Pendidikan, 2006. Model Pembelajaran Tematik Kelas Awal SD, Departemen Pendidikan Nasional, Jakarta.

Dhiniaty Gularso, 2010. Pemetaan Kemampuan Guru Sekolah Dasar Kelas I, II dan III dalam Pembelajaran Menggunakan Pendekatan Tematik di Kecamatan Kasihan, Kabupaten, 
Bantul, Provinsi Daerah Istimewa Yogyakarta. Jurnal Simbiosis, Prodi Pendidikan Biologi Jurusan PMIPA FKIP Universitas Patimura Ambon Vol. 7 No. 1 April 2010 No. ISSN 1829-5452 Hal 187-193.

Dhiniaty Gularso, 2011. Potret Pelaksanaan Pembelajaran Tematik Di Sekolah Dasar Kabupaten Bantul Daerah Istimewa Yogyakarta. Jurnal Pendidikan dan Humaniora "Kompetensi" FKIP UNIBA Vol. 2 No. 1, Juli 2011 No. ISSN 2087-0485 hal. 19-29.

Peraturan Menteri (2006). Peraturan Menteri Nomor 6 Tahun 2007 Tentang Kurikulum Tingkat Satuan Pendidikan.
Peraturan Menteri (2006). Peraturan Menteri Nomor 22 Tahun 2006 Tentang Standar Isi untuk Pendidikan Dasar dan Menengah.

Peraturan Menteri (2006). Peraturan Menteri Nomor 23 Tahun 2006 Tentang Standar Kompetensi Kelulusani untuk Pendidikan Dasar dan Menengah.

Peraturan Pemerintah (2005). Peraturan Pemerintahi Nomor 19 Tahun 2005 Tentang Standar Nasional Pendidikan.

Sugiyono, 2007. Metode Penelitian Pendidikan, Pendekatan Kuantitaif, Kualitatif dan $R \& D$, Penerbit : Alfabeta, Bandung. 